\title{
Massive Subaponeurotic Haemorrhage in Babies of African Origin
}

\author{
R. J. ROBINSON and MARY A. ROSSITER \\ From the Institute of Child Health, and Nuffield Neonatal Research Unit, Hammersmith Hospital, London W.12
}

Newborn babies of African origin occasionally undergo massive haemorrhage into the soft tissues of the scalp. The resulting haematoma differs from the more usual variety of cephalhaematoma in being anatomically subaponeurotic, not subperiosteal. Not being confined by periosteal attachments, the haematoma is not limited to the area overlying a single skull bone, but extends through the soft areolar tissue of the scalp and covers the whole calvarium beneath the epicranial aponeurosis. Consequently this variety of haematoma may be far larger than a subperiosteal cephalhaematoma, and the blood loss into it may almost exsanguinate the infant. The purposes of this report are first to draw attention to the occurrence of this condition in African and West Indian babies and to the severity of the blood loss, and secondly to describe a simple rough method of calculating the extent of blood loss.

\section{Clinical Features}

During the past 5 years, 5 cases of massive subaponeurotic haemorrhage have been observed, all in African or West Indian babies. The clinical findings were similar in all. The swelling beneath the scalp appeared within the first 2 days of life. It extended over the entire calvarium, being bounded by the attachments of the epicranial aponeurosis. The sutures and fontanelles could be felt with difficulty, if at all. The babies showed signs of considerable blood loss and shock; all except one required blood transfusions of one-third to one-half their estimated blood volume. 2 babies also had some gastro-intestinal bleeding. None of the 5 had received prophylactic vitamin $K$. In Cases 1 and 3, the prothrombin time before administration of vitamin $\mathrm{K}$ and blood was more than 60 seconds; in the other 3 cases prothrombin time was not estimated before vitamin $\mathrm{K}$ was given. All 5 babies were initially breast fed. Illustrative case reports are given below, and the main features of the 5 cases are summarized in the Table.

Received June 6, 1968.
Case 1. A 3300 g. boy was born at $39 \frac{1}{2}$ weeks gestation after a normal pregnancy to a 21-year-old Nigerian primigravida. Labour lasted 13 hours, forceps being applied in the second stage for maternal distress. The baby was in the persistent occipitoposterior position at delivery. He breathed spontaneously within one minute. Considerable caput was noticed at birth. During the next 48 hours he developed marked swelling beneath the scalp and in front of the ears. At 48 hours he was very pale and vomited some bright red blood. His head circumference was now $38 \mathrm{~cm}$. The scalp was tight with a swelling beneath it covering the whole calvarium. The swelling could be pitted and the sutures and fontanelles were just palpable through it. $\mathrm{Hb}$ was $7 \cdot 8 \mathrm{~g} . / 100 \mathrm{ml}$. and prothrombin time more than 60 seconds. $5 \mathrm{mg}$. vitamin $\mathrm{K}$ analogue (Konakion) were given intramuscularly and $105 \mathrm{ml}$. blood were transfused. Two days later his $\mathrm{Hb}$ was $16.0 \mathrm{~g} .100 \mathrm{ml}$. The swelling under the scalp slowly subsided over the next 2 weeks and his recovery was uneventful.

Case 5. A 3740 g. boy was born to a 19 -year-old Jamaican primigravida after a normal pregnancy of uncertain duration. The cervix was fully dilated after 17 hours labour, but the baby's position was persistently right occipito-lateral. Rotation was attempted using Keilland's forceps, but after forceps extraction the position of the head was still right occipito-lateral. At birth the baby's condition was excellent, with Apgar score 10. At 26 hours his mother noticed that be was breathing abnormally. $\mathrm{He}$ was found to be cold $\left(35^{\circ} \mathrm{C}\right.$.), very pale, and restless, with grunting respirations of $80 / \mathrm{min}$. The head circumference was $39.5 \mathrm{~cm}$., and there was a tense swelling beneath the scalp covering the entire calvarium and extending down in front of the ears. The fontanelles and sutures could not be palpated through the swelling. He was given $1 \mathrm{mg}$. vitamin $K$ analogue intramuscularly, and a rapid transfusion of $50 \mathrm{ml}$. blood in 20 minutes, followed by a further $125 \mathrm{ml}$. over the next 10 hours. His colour improved after the initial rapid transfusion, and his respiratory rate gradually fell to $40 / \mathrm{min}$. during the next 8 hours. The head circumference increased to $41 \mathrm{~cm}$. 2 hours after the transfusion was started, but over the next 2 days the swelling under the scalp resolved rapidly, the head circumference falling to $37 \mathrm{~cm}$. 
TABLE

Clinical Data, Calculated Blood Loss, and Volume Transfused in 5 Babies with Massive Subaponeurotic Haemorrhage

\begin{tabular}{|c|c|c|c|c|c|c|c|c|c|}
\hline $\begin{array}{l}\text { Case } \\
\text { No. }\end{array}$ & Nationality & Sex & $\begin{array}{c}\text { Gestational } \\
\text { Age } \\
\text { (wk.) }\end{array}$ & $\begin{array}{c}\text { Birth- } \\
\text { weight } \\
\text { (g.) }\end{array}$ & Delivery & $\begin{array}{c}\text { Time of } \\
\text { Onset of } \\
\text { Scalp } \\
\text { Swelling } \\
\text { (hr.) }\end{array}$ & $\begin{array}{c}\text { Volume of } \\
\text { Blood } \\
\text { Transfused } \\
\text { (ml.) }\end{array}$ & $\begin{array}{c}\begin{array}{c}\text { Calculated } \\
\text { Blood Loss }\end{array} \\
\frac{C^{3}-C_{\mathrm{kx}^{3}}}{12 \pi^{2}} \mathrm{ml} .\end{array}$ & $\begin{array}{l}\text { Calculated } \\
\text { Loss as \% of } \\
\text { Blood } \\
\text { Volume }\end{array}$ \\
\hline 1 & Nigerian & $\mathbf{M}$ & $39 \frac{1}{2}$ & 3300 & $\begin{array}{l}\text { Forceps } \\
\text { occipito- } \\
\text { posterior } \\
\text { position }\end{array}$ & 24 & 105 & 102 & 37 \\
\hline $\begin{array}{l}2 \\
3\end{array}$ & $\begin{array}{l}\text { Trinidadian } \\
\text { Grenadan }\end{array}$ & $\underset{F}{M}$ & $\begin{array}{r}39 \frac{1}{2} \\
? 42\end{array}$ & $\begin{array}{l}3240 \\
2760\end{array}$ & $\begin{array}{l}\text { Normal } \\
\text { Vacuum } \\
\text { extrac- } \\
\text { tion }\end{array}$ & $\begin{array}{r}6 \\
48\end{array}$ & $\begin{array}{c}67 \\
140^{\star}\end{array}$ & $\begin{array}{l}85 \\
93\end{array}$ & $\begin{array}{l}31 \\
41\end{array}$ \\
\hline 4 & Nigerian & $\mathbf{M}$ & $38 \frac{1}{2}$ & 3640 & $\begin{array}{l}\text { Vacuum } \\
\text { extrac- } \\
\text { tion }\end{array}$ & 24 & None & 74 & 24 \\
\hline 5 & Jamaican & $\mathbf{M}$ & $? 42$ & 3740 & $\begin{array}{l}\text { Keilland } \\
\text { forceps }\end{array}$ & 24 & 175 & 182 & 58 \\
\hline
\end{tabular}

^This baby also had some gastro-intestinal bleeding.

$\mathrm{Hb}$ was $6 \cdot 3 \mathrm{~g} . / 100 \mathrm{ml}$. before transfusion and $14 \cdot 0$ g. $/ \mathrm{ml}$. on the day after transfusion. On that day only $30 \%$ of the circulating red cells contained fetal $\mathrm{Hb}$ (Kleihauer method). Assuming that before haemorrhage the baby's normal blood volume would have been 310 ml., with $\mathrm{Hb} 16.0$ g./100 ml. (Oski and Naiman, 1966) the following estimates of the volume of blood lost from the circulation could be made: (a) from the extent of fall in $\mathrm{Hb}$ level after haemodilution-190 ml.; (b) from the restoration of $\mathrm{Hb}$ level after transfusion of $175 \mathrm{ml}$. blood-213 ml.; (c) from the proportion of fetal cells after transfusion-approximately $200 \mathrm{ml}$. His recovery was uneventful. As the swelling disappeared over the 5 days after transfusion, $\mathrm{Hb}$ gradually rose from 14.0 to $18.4 \mathrm{~g} . / 100 \mathrm{ml}$., suggesting that some of the blood lost into the haematoma may subsequently have been reabsorbed intact into the circulation.

\section{Calculation of Volume of Haematoma}

It is clear from the clinical histories that dangerously large volumes of blood may be lost from the circulation into this kind of haematoma. If certain simplifying assumptions are made about the geometry of the baby's head and of the haematoma, the volume of the latter may be calculated from the head circumference. If the part of the head covered by haematoma is assumed to be a hemisphere and if the haematoma is distributed evenly over the surface of the calvarium so that the scalp is concentrically displaced from the skull (which appeared to be so in our five infants), then the volume of the haematoma will be the difference between the volumes of the outer hemisphere bounded by the scalp and the inner hemisphere bounded by the skull. The volume of a hemisphere is $2 / 3 \pi r^{3}$, where $r$ is the radius, or $\frac{C^{3}}{12 \pi^{2}}$ where $C$ is the circumference $(=2 \pi r)$. Then if $C$ is the measured head circumference in $\mathrm{cm}$., and
$C_{\mathrm{Ex}}$ the expected head circumference, the volume of the haematoma in $\mathrm{cm}$. is given by

$$
V=\frac{C^{3}-C_{\mathrm{Ex}}{ }^{3}}{12 \pi^{2}}
$$

Ideally, $C_{\mathrm{Ex}}$, the expected head circumference would be measured before the appearance of the swelling. If, however, such a measurement is not available, the 50th centile for head circumference at the baby's gestational age may be used. The normal variation of head circumference is such that error introduced in the calculation would be less than $50 \mathrm{ml}$. in $90 \%$ of cases and less than $65 \mathrm{ml}$. in $97 \%$ of cases.

The calculated volume of the haematoma in each case is given in the Table and compared with the volume of blood transfused, the amount being decided on independent clinical grounds.

\section{Discussion}

Subaponeurotic haemorrhage is not listed among the manifestations of haemorrhagic disease of the newborn in modern paediatric textbooks, and discussions of cephalhaematoma are generally restricted to the common subperiosteal variety. In a lecture on cephalhaematoma, West (1874) referred to pouring out of blood beneath the occipitofrontalis muscle (i.e. the epicranial aponeurosis) after trauma, but it is clear that this was an aside referring to older children. Ashby and Wright (1896) mentioned that cephalhaematoma might rarely be in the subaponeurotic layer of the scalp. In more recent published reports we have been able to find 7 reports comprising 40 cases of massive scalp haemorrhage (Venezia and Jahier, 1959; Bernard, Sansot, and Rapezzi, 1960; Leonard and Anthony, 1961; Van der Horst, 1963; Kozinn et al., 
1964; Valentine, 1964; Barrow and Peters, 1968), and 2 mentions of 5 cases of 'sub-galeal haematoma' in haemorrhagic disease of the newborn with no other clinical details (Aballi and de Lamerens, 1962; Sutherland, Glueck, and Gleser, 1967). The 10 babies described by Leonard and Anthony (1961) and by Van der Horst (1963) were almost identical in their clinical features to ours.

The factors which apparently predispose to subaponeurotic haemorrhage are haemorrhagic disease of the newborn, African parentage, and possibly traumatic birth. Prolonged prothrombin time indicating haemorrhagic disease has been shown in 20 of 32 cases described. In most of the remaining cases the test was not performed before vitamin $\mathrm{K}$ was given. None of the babies reported here had received prophylactic vitamin $\mathrm{K}$.

All 5 of our cases were directly or indirectly of African origin; they were drawn from approximately 2800 liveborn babies of such racial origin born in this hospital over the 5-year period. In the same period there were approximately 9400 Caucasian livebirths and none of these infants developed massive subaponeurotic haemorrhage $\left(x^{2} 12 \cdot 7, \mathrm{p}<0.001\right)$. Van der Horst also saw the condition exclusively in African babies and the cases of Venezia and Jahier (1959), of Leonard and Anthony (1961), and of Barrow and Peters (1968) were non-Caucasian. Valentine (1964) saw one case in a Caucasian baby but agreed that it must be a great rarity in such infants. Three possible explanations could be offered for a higher incidence in African babies: that there is an increased incidence of haemorrhagic disease in such babies; or that they have an anatomically different scalp which predisposes to subaponeurotic haemorrhage; or that they more often sustain trauma to the scalp at birth. There is indeed evidence that haemorrhagic disease of the newborn due to deficiency of prothrombin and of factors IX and X is 3 to 4 times commoner in African than in white infants (Lanzkowsky et al., 1967). There is also evidence that breast-feeding predisposes to haemorrhagic disease (Sutherland et al., 1967), and there is a somewhat higher incidence of breast-feeding among mothers of African descent in this hospital. However, it is not clear whether the effects of African parentage and of breast-feeding on the incidence of haemorrhagic disease are interrelated or independent.

The place of trauma in the production of these haematomas is uncertain: 4 out of 5 of our cases had difficult instrumental deliveries, and we felt there had been a significant degree of trauma which had been important in determining the site of the haemorrhage. However, of Van der Horst's 9 cases, 3 had normal deliveries and 3 were born by caesarean section.

At present there does not seem to be enough data to decide whether the relatively high incidence of subaponeurotic haemorrhage in African babies is solely due to their increased liability to haemorrhagic disease, or whether an additional anatomical or traumatic factor needs to be invoked.

The practical importance of this condition is that sufficient blood may be lost into the haematoma to endanger the baby's life (Venezia and Jahier, 1959; Leonard and Anthony, 1961; Van der Horst, 1963). It is often difficult to believe that the baby can have lost half its blood volume or more into the swelling under the scalp (Valentine, 1964). The formula we have given for estimating the size of the haematoma is useful in providing a rapid method of calculating the probable volume of blood loss. The Table shows that the blood loss calculated from the head circumference corresponded well in most cases with the amount of blood transfused. The amount of transfusion required was decided on clinical grounds at the time and was not influenced by the calculations that were made retrospectively; the only baby who did not require transfusion was also the only one in whom the formula indicated a blood loss of less than $25 \%$ of the estimated blood volume (Case 4). In Case 5 the extent of blood loss was estimated in three different ways from haematological data (see above). All three estimates agreed closely and their mean was $200 \mathrm{ml}$. compared with $182 \mathrm{ml}$. calculated from the formula.

Differentiating the formula with respect to $C$, the measured head circumference, gives

$$
\frac{d V}{d C}=\frac{C^{2}}{4 \pi^{2}}
$$

$\frac{d V}{d C}$ is approximately equal to $\frac{\triangle V}{\triangle C}$ which is the volume of blood in $\mathrm{ml}$. lost per $\mathrm{cm}$. increase in head circumference. When $C=37 \mathrm{~cm} ., \frac{d V}{d C}=$ $35 \mathrm{ml} . / \mathrm{cm}$., and when $C=40 \mathrm{~cm} ., \frac{d V}{d C}=41 \mathrm{ml} . / \mathrm{cm}$. Over the probable range of head circumference therefore, a rough rule is that the volume of blood in the haematoma is $38 \mathrm{ml}$. for each $\mathrm{cm}$. by which the head circumference exceeds that expected.

\section{Summary}

Five babies of African origin sustained massive haemorrhage into the soft areolar tissue beneath the epicranial aponeurosis during the first $\mathbf{4 8}$ hours 
of life. 4 required large blood transfusions. The amount of blood lost in ml. corresponded well with the formula $\frac{C^{3}-C_{\mathrm{Ex}}{ }^{3}}{12 \pi^{2}}$, where $C$ is the actual and $C_{\mathrm{Ex}}$ the expected head circumference in $\mathrm{cm}$. The blood loss is approximately $38 \mathrm{ml}$. for each $\mathrm{cm}$. by which the actual head circumference exceeds that expected. Blood losses amounted to onequarter to over one-half the total blood volume.

\section{REFERENCES}

Aballi. A. J., and de Lamerens, S. (1962). Hemorrhagic disease of the newborn: two forms with different hemostatic defects. Amer. 7. Dis. Child., 104, 475.

Ashby, H., and Wright, G. A. (1896). The Diseases of Children, Medical and Surgical, 3rd ed., p.19. Longman, London.

Barrow, E., and Peters, R. L. (1968). Exsanguinating haemorrhage into the scalp in newborn infants. S. Afr. med. F., 42, 265.
Bernard, R., Sansot, M., and Rapezzi (1960). Anémie par hématome extensif du cuir chevelu chez le nouveau-né. Pédiatrie, $15,588$.

Kozinn, P. J., Ritz, N. D., Moss, A. H., and Kaufman, A. (1964). Massive hemorrhage: scalps of newborn infants. Amer. $\mathcal{F}$. Dis. Child., 108, 413.

Lanzkowsky, P., Joffe, H. S., Levy, S., Nossel, H. L., and Mibashan, R. S. (1967). Coagulation studies in mothers and healthy neonates, with an inter-racial survey of clotting factors in the newborn. S. Afr. med. F., 41, 1039.

Leonard, S., and Anthony, B. (1961). Giant cephalhematoma of newborn with hemorrhagic disease and hyperbilirubinemia. Amer. F. Dis. Child., 101, 170.

Oski, F. A., and Naiman, J. D. (1966). Haematologic Problems in the Newborn, p. 8. Saunders, Philadelphia and London.

Sutherland, J. M., Glueck, H. I., and Gleser, G. (1967). Hemorrhagic disease of the newborn: breast feeding as a necessary factor in the pathogenesis. Amer. F. Dis. Child., 113, 524.

Valentine, G. H. (1964). Exsanguinating cephalhematoma: a report of two cases. Canad. med. Ass. F., 91, 177.

Van der Horst, R. L. (1963). Exsanguinating cephalhaematomata in African newborn infants. Arch. Dis. Childh., 38, 280.

Venezia, R., and Jahier, C. (1959). Sur une forme clinique particulière de la maladie hémorrhagique du nouveau-né : l'hématome sous-cutané crânien extensif. Pédiatrie, 14, 772.

West, C. (1874). Lectures on the Diseases of Infancy and Childhood, 6th ed., p. 60. Longman, London. 